Vol. XXIII No 12017

\title{
MANNERS OF PERFORMING TERRORIST ATTACKS
}

\author{
Tomasz BĄK \\ University of Information Technology and Management in Rzeszów, Poland \\ tbak@wsiz.rzeszow.pl
}

\begin{abstract}
The article below presents the evolution of terrorist tactics over the years. It describes the basic types of terrorist attacks divided by the place of attack and by means used to execute it. The recent ways of performing terrorist attacks by terrorist organizations have been presented on the basis of accessible sources and statistics. The last part of the article is dedicated to expected changes of terrorist attack tactics in the future.
\end{abstract}

\section{Keywords: terrorism, terrorist attack, performance manner}

\section{Introduction}

Terrorism has become one of the most serious threats of the $21^{\text {st }}$ century, although the phenomenon has been known since antiquity. Over the centuries, both the objectives and manners of conducting terrorist activity changed.

\section{Statistical presentation of terrorist attacks}

It is undeniable, however, that currently attacks have the following main objectives:

- to glorify strength as the only method of political fight and the most effective one,

- to show cruelty and lack of moral scruples in the actions taken,

- to give rise to a widespread, strong sense of danger,

- to gain publicity w mass media,

- to execute political blackmail and enforce specific political acts or changes. [1]

To support the above statement that terrorism is the most serious threat nowadays, below the statistics of terrorist attacks in 2015 are given.
Table 1: Number of attacks and casualties in particular months of 2015

\begin{tabular}{|r|r|r|r|r|}
\hline Month & $\begin{array}{c}\text { No. of } \\
\text { attacks }\end{array}$ & $\begin{array}{c}\text { No. } \\
\text { of the } \\
\text { dead* }\end{array}$ & $\begin{array}{c}\text { No. of } \\
\text { the } \\
\text { injured* }\end{array}$ & $\begin{array}{c}\text { No. of } \\
\text { the } \\
\text { abducted/ } \\
\text { hostages }\end{array}$ \\
\hline January & 1270 & 2340 & 2781 & 1726 \\
\hline February & 1078 & 2127 & 2713 & 894 \\
\hline March & 903 & 2378 & 2829 & 1214 \\
\hline April & 928 & 2919 & 2650 & 1155 \\
\hline May & 1017 & 2676 & 2705 & 1725 \\
\hline June & 929 & 2727 & 3407 & 535 \\
\hline July & 986 & 2946 & 3645 & 1204 \\
\hline August & 993 & 2400 & 3349 & 1260 \\
\hline September & 881 & 2266 & 3491 & 543 \\
\hline October & 1040 & 2300 & 2722 & 877 \\
\hline November & 928 & 1610 & 2581 & 769 \\
\hline December & 821 & 1639 & 2447 & 287 \\
\hline Total & 11774 & $\mathbf{2 8 3 2 8}$ & $\mathbf{3 5 3 2 0}$ & $\mathbf{1 2 1 8 9}$ \\
\hline & & & $*$ incl. the terrorists
\end{tabular}

Source: Annex of Statistical Information

Country Reports on Terrorism 2015[2] 
Table 2: 10 states with the highest number of terrorist attacks in 2015

\begin{tabular}{|r|r|r|r|r|r|r|}
\hline State & $\begin{array}{r}\text { No. of } \\
\text { attacks }\end{array}$ & $\begin{array}{r}\text { No. of the } \\
\text { dead * }\end{array}$ & $\begin{array}{c}\text { Average No. } \\
\text { of the dead } \\
\text { per attack }\end{array}$ & $\begin{array}{r}\text { No. of the } \\
\text { injured * }\end{array}$ & $\begin{array}{r}\text { Average No. } \\
\text { of the injured } \\
\text { per attack * }\end{array}$ & $\begin{array}{r}\text { No. of the } \\
\text { abducted/ } \\
\text { hostages }\end{array}$ \\
\hline Iraq & 2418 & 6932 & 2.99 & 11856 & 5.23 & 3982 \\
\hline Afghanistan & 1708 & 5292 & 3.24 & 6246 & 4.00 & 1112 \\
\hline Pakistan & 1009 & 1081 & 1.10 & 1325 & 1.36 & 269 \\
\hline India & 791 & 289 & 0.38 & 508 & 0.68 & 862 \\
\hline Nigeria & 589 & 4886 & 9.29 & 2777 & 7.67 & 1341 \\
\hline Egypt & 494 & 656 & 1.34 & 844 & 1.73 & 24 \\
\hline Philippines & 485 & 258 & 0.54 & 548 & 1.16 & 119 \\
\hline Bangladesh & 459 & 75 & 0.16 & 691 & 1.52 & 4 \\
\hline Libya & 428 & 462 & 1.24 & 657 & 1.85 & 764 \\
\hline Syria & 382 & 2748 & 7.99 & 2818 & 9.78 & 1453 \\
\hline World total & $\mathbf{1 1 7 7 4}$ & $\mathbf{2 8 3 2 8}$ & $\mathbf{2 . 5 3}$ & $\mathbf{3 5 3 2 0}$ & $\mathbf{3 . 3 0}$ & $\mathbf{1 2 1 8 9}$ \\
\hline
\end{tabular}

Source: Annex of Statistical Information Country Reports on Terrorism 2015 [3]

\section{Types of terrorist attacks}

Considering the basic division by the place of the attack, one may distinguish three basic types: air attacks, sea attacks and land attacks.

Using various types of aircrafts as means to strike objects situated on the ground or on sea, one may cause great losses and extensive destruction. A typical example of such an attack is the one on $11^{\text {th }}$ September 2001 on the World Trade Center and Pentagon buildings.

Acts of air terror include [4]:

- hijacking a passenger plane or a different aircraft filled with fuel or explosives to destroy a particular object or attack civilians by hitting the target with the hijacked aircraft;

- using an aircraft (crew-operated or robotic) as a transport means to drop (spray) toxic (chemical or biological) substances;

- using an aircraft with a nuclear cargo or a "dirty bomb" to destroy an important object (e.g. a nuclear power plant or a dam) or contaminate an area.

The threat of such an attack may only be minimised by careful controls of passengers and proper airport protection.

A terrorist action on sea is another way to perform an attack. Marine areas have conditions favourable to performing such actions, due to e.g.:
- the depth of waters on sea communication routes which allows for planting bottom mines;

- short time of icing (appearing practically only in the coastal zone), as icing disallows actions of terrorist groups using quick motor boats.

Prevention of such actions consists mainly in having sea areas patrolled more intensively by naval units and by special anti-terrorist teams composed of special forces units.

The last basic types of terrorist actions are attacks on land. They concern mostly such objects as:

- infrastructure facilities which are the seats of central or local government authorities;

- other countries' diplomatic facilities;

- critical infrastructure facilities (power plants, dams, important industrial plants, etc.);

- army facilities;

- "soft facilities" (railway stations, subway, cinemas and theatres, mass transport means).

One may also divide terrorist attacks by the means used to perform them. Some of the basic types of attacks are as follows:

- attack on assemblies of population, selected people or facilities using firearms or missiles; 
- terrorist attacks in public places using explosives;

- hijacking or detaining means of public transport with passengers as hostages;

- the use of own or stolen vehicle to drive into crowds of people - the newest method.

According to the available statistics, bomb attacks are one of the most frequent forms of terrorist attacks. In the $1980 \mathrm{~s}$, bomb attacks made up as much as $67 \%$ of all attacks. That stems mainly from the following factors: the ease of planting explosives, relative ease of obtaining them, and the possibility to cause extensive damage. Moreover, the attackers do not have to be on site at the moment of the attack. The range of bomb attacks is extremely broad: from small bombs (or even dummy bombs) aimed at terrorising or killing an individual up to huge explosive charges meant to cause numerous casualties. It is also possible to use civil objects as bombs, such as tankers with flammables, oil carriers, or passenger planes with full fuel tanks. Also, numerous options exist as to placing explosives on the site of the attack (planted, placed in vehicles, sent by mail, as well as thrown into the target area). There are various ways to detonate them, as well (delay, cord, radio-activated and other fuses), including the fact that it is possible to combine several detonation manners to increase the probability of detonation and avoid disarming by bomb-disposal experts [5]. The statistics put attacks with the use of firearms at the second place. In most cases, guns are used for attacks on a limited scale, although there were cases of attacks with the use of firearms with many casualties. Terrorists usually prefer handguns (pistols and revolvers) and small machine guns, sometimes also assault rifles. Other kinds of guns are sometimes used, like assault or machine guns, but those cause difficulties in covert transport.

In the recent years, hostage situations have become a mass phenomenon. Taking hostages allows not only to publicise one's own cause, but also to gain direct concessions of the authorities (access to the media, freeing prisoners, etc.). Three types of hostage situations can be defined:

- kidnapping an individual;

- abducting vehicles (planes, buses, ships);

- seizing stationary facilities.

Beside the above-listed forms of terrorist attacks, there can be other, less frequent and/or typical ones. Those include activities which consist in instigating riots in jails or in the streets and similar actions. As a rule, beside the terrorists themselves they engage large groups of people loosely connected to the terrorists.

The pie chart below presents manners of performing terrorist attacks in 2015.

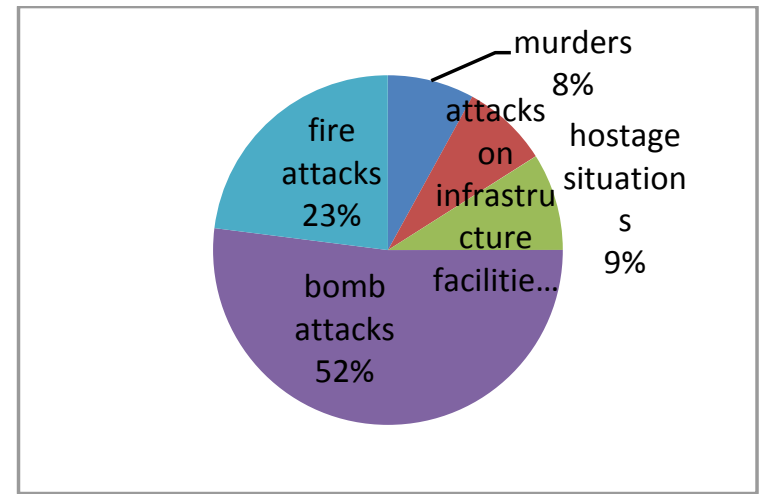

Fig. 1. Manners of performing terrorist attacks in 2015

Source: Annex of Statistical Information Country Reports on Terrorism 2015 [6]

Additionally, 2015 saw 101 terrorist attacks without the use of guns or explosives. Such attacks usually employed chemical weapons, or the use of vehicles as a means to ram into people.

A yet separate attack is an IT terrorist attack, which consists mainly in hacking systems, paralysing information flow and falsifying data. It is also possible to block information, manipulate it, destroy data or electronically destroy a whole IT system.

Of course, attacks on IT systems can be combined with other types of terrorist attacks, or rather be an introduction to the 
actual attack. The modern world has many IT systems whose disruption could have a negative impact on a state's functioning and citizen security. Particularly serious are threats to systems operating in the energy, waterworks or gas pipeline sectors or in emergency or uniformed services. Paralysing those can cause paralysis of the whole state.

So far, such attacks did not cause casualties or a serious threat to human life.

One of the most dangerous kinds of attack is a biological terrorist attack. Characteristic features of such actions are as follows:

- quick spread of the microbes (bacteria, viruses),

- lack of effective medicine,

- difficulty in prompt diagnosis of the cause of the diseases and deaths,

- misleading symptoms as the disease develops,

- great economy of the weapon, for any small amount of the substance proliferates and moves together with its carriers (people, animals, etc.),

- the effect is not immediately noticeable,

- there may appear secondary effects such as transferring the disease to other individuals and the possibility of an epidemics,

- the contamination element may be any element of the ecosystem (water, air, soil, etc.),

- no possibility to protect oneself in case of mass use of the weapon.

When considering the threat of using biological weapons for an attack, factors which decide on that must be mentioned. These certainly include:

- easy gaining (based on using the pharmaceutical industry, small laboratories),

- low costs of use (the costs of causing comparable losses among people per 1 $\mathrm{km}^{2}$ are: for conventional weapons 2000 USD, for nuclear weapons -800 USD, for biological weapons - 1 USD),

- an extremely effective scale of use considering fatal effects and evoking infectious diseases,

- invisibility during the attack,

- easy hiding and transport,

- extreme difficulty in quick detection of the cause of diseases and deaths, as in its incubation time the disease may often have atypical and misleading symptoms.

\section{FORMS (MANNER) OF USING BIOLOGICAL WEAPONS}

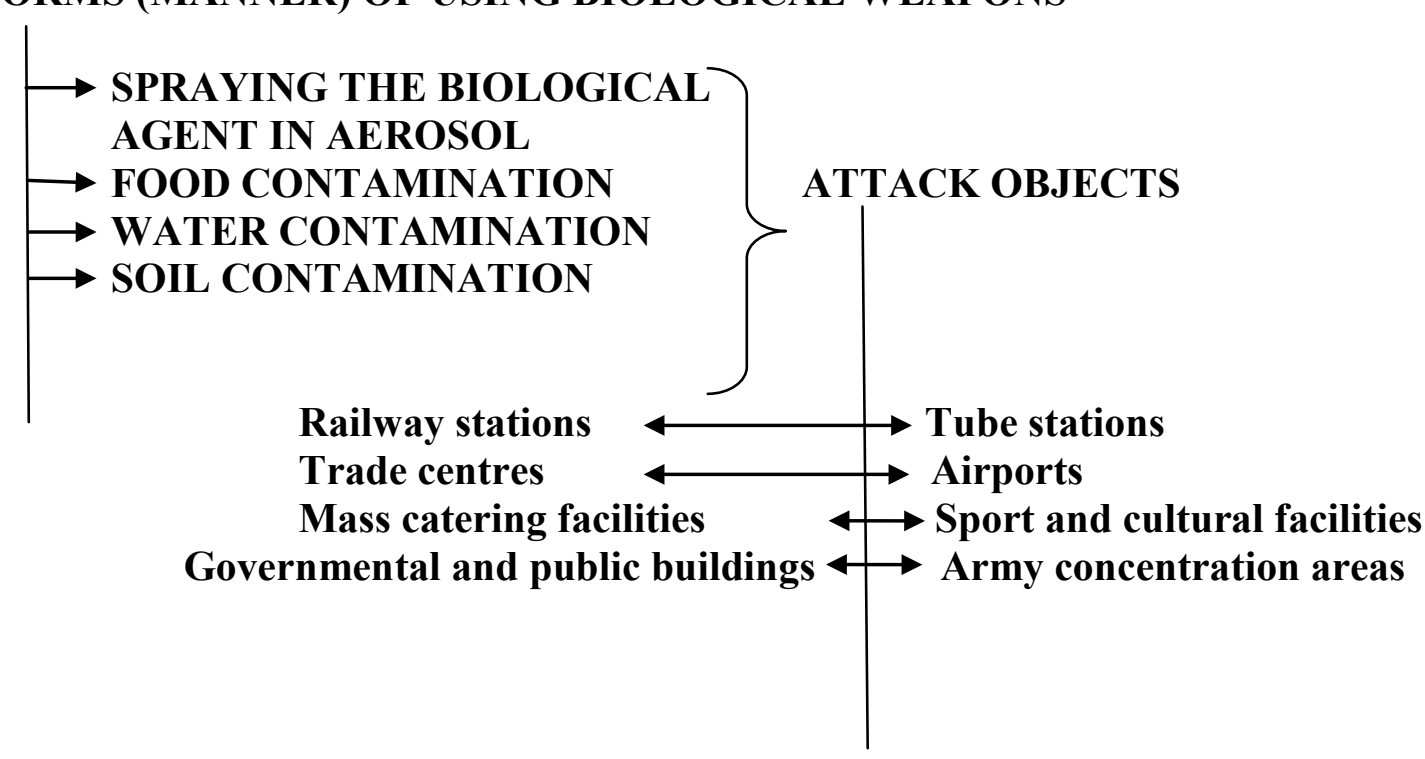


Another type is chemical terrorist attacks, which consist in using toxic warfare agents and dangerous chemical substances (toxic industrial waste). The main aim of such attacks is to cause maximum damages and casualties among civilians (attacking "soft targets", critical infrastructure facilities, etc). Currently in most countries in the world and in Europe there are very numerous plants using dangerous materials which may cause serious threat for people and the environment. For that reason they are potential targets of terrorist attacks.

One of the greatest threats in the time of peace, as well as in war, is contamination with toxic industrial waste.

It is worth listing here the manners of performing terrorist attacks used over centuries.

Up until WWI, individual assassination attempts dominated terrorism. The most frequent targets of attacks were thus carefully selected objects, and the victims included mainly representatives of the then political elites - kings, ministers, government heads. After 1945, terrorism grew in cruelty, both in the Western world and in non-European campaigns. Particularly frequent targets were police officers and soldiers, as that gave the fight a more guerrilla-like nature, and allowed the attackers to feel true fighters rather than terrorists. As a matter of fact, in many cases the terrorist attacks were indeed only part of guerrilla-type fights. Sometimes, the combat turned into regular wars. In that situation, terrorists soon changed their manner of action and instead of killing, kidnapped their targets, following the experiences of South American guerrillas. That required greater skill and a more extensive logistic base, yet the results were much more promising. In exchange for the hostage, a whole group of jailed terrorists could be freed. What was more, successful kidnapping of a relatively well-known figure of political or economic life held the attention of public opinion for a longer time - for several days, the media would almost non-stop cover not just the action itself, but also the objectives of the group behind it. The fate of one or more hostages, held by terrorists and remaining at their mercy, would be the number-one topic in the media for a while [7].

The dominating method of the 1970s was bomb attacks, often aimed at civilians. It ought to be noted, however, that it was a difficult method to apply. In the 1970s, bombs usually consisted of several dynamite sticks and fuses, stolen from construction sites or quarries and linked to common alarm clocks. Such a construction was dangerous not only to the potential target, but also to the attacker. Later, thanks to modern explosive materials received from rich sponsors, that danger was gradually reduced. After suitable training, terrorists used professional equipment and weapons just as well as the army did. It is thus no wonder that in the European separatist terrorism of $1960 \mathrm{~s}$ and $70 \mathrm{~s}$, violence was mainly used against the security forces of the attacked states, and to a much lesser extent against civilians.

Attacks were performed mainly with the use of two methods: planting bombs and hijacking. A method introduced to terrorism by the Palestinian movement was plane hijacking. It became a true plague between the 1960s and 70s. Some of the hijacking actions had very spectacular dimensions. That method - in various variants - was also followed by other terrorist groups. As a result, in 1969-1972 as many as 286 hijacks occurred.

Plane hijacking was soon commonly deemed an effective method, as the accompanying drama forced authorities to make concessions. Relatively high numbers of victims and their unknown fate gave such actions longer attention and publicity than even the most successful (from the terrorists' points of view) bomb attacks or shootings.

Introducing suicide attacks marked another milestone in the development of terrorism. First of all, such an idea facilitated 
planning. Hiding the charge allowed a terrorist to come close to the target without much problem, almost unnoticed. Also, when preparing the attack it was not necessary to be concerned with planning an escape route. An additional benefit of suicide attacks is their extremely powerful impact on outside observers.

Suicide terrorist attacks are performed in various manners. Poorer local groups usually send out individual terrorists with special belts filled with TNT and metal pieces. Strictly religious terrorism, which has more extensive opportunities, most frequently uses cars filled with explosives. Such attacks were at first aimed at carefully selected objects - checkpoints, embassies, barracks, and the people they held. Then in order to increase the impact, random objects and civilian targets were chosen more and more frequently. The climax of such actions was undoubtedly the attacks of September 11, 2001. They became for many a proof of the radical changes occurring in terrorism. The previously dominating moderation, expressed in choosing methods of a maximum effect with a minimum of casualties, was replaced with "total terrorism", aimed at killing the greatest possible numbers.

Today's religious terrorists use a far broader range of methods than their rightwing predecessors. Beside the abovementioned suicide attacks, a significant number of attacks involve kidnapping, yet different from what has been seen before. The aim of such kidnappings is not so much money or other immediate benefits, but terror. Those kidnappings turn into prolonged series of murders. One of the elements are maximalist demands which are impossible to meet, and brutal executions of hostages after the ultimatum's deadline. An integral part of that method is publishing films from those executions online.

One of the most recent manners of performing terrorist attacks consists in hijacking a truck and then ramming the vehicle into crowds of people.
The first attack using a car was executed by Mohammed Reza Taheri-azar, who in March 2009 drove into a crowd of students on the campus of the University of North Carolina, injuring nine people.

Another such attack occurred in 2009 in the Netherlands. During a parade including the Dutch Royal Family, Karst Roeland Tates drove his car into the parade participants. Before his death he stated he had wanted to kill the Queen.

After that attack, in 2010 the US Department of Homeland Security issued a warning concerning that new method of performing terrorist attacks. According to experts, such attacks are easy to execute wherever there are crowds, e.g. during national holidays or sports events. The Americans warned that terrorists needed no special training for such an attack, neither did they need to obtain firearms or explosives.

In October 2014, Martin Couture-Rouleau, an Islam convert, rammed into two soldiers in Saint-Jean-sur-Richelieu, Canada, killing one and causing serious injury to the other one. The perpetrator was shot after a police chase. In that same month, Abdel-Rahman Shaloudi rammed his car into a train station in Israel, killing a three-month-old baby and a 22-year-old tourist from Ecuador.

Other attacks of the kind took place in France in December 2014 - in Dijon and Nantes - when men yelling "Allahu Akbar" rammed into crowds. The authorities stated, however, that those men suffered from mental illnesses and had no contact to terrorist organisations.

On the $14^{\text {th }}$ July 2016, a fast-driven truck rammed into crowds celebrating Bastille Day in Nice. The terrorist killed people as he drove through the promenade. 84 were killed, with over 200 injured. The victims included French citizens and foreigners, also many children. Two Poles were also killed.

The events in Nice showed that a car can become an instrument of terror. Using a 
vehicle to attack people has become much of a standard in terrorist activities.

On the $19^{\text {th }}$ December 2016, another such terrorist attack occurred in Berlin. A truck with Polish number plates was driven into the Christmas market in the city centre. The attack killed 11 people in the Christmas market and the driver of the Polish truck, who was probably shot by the terrorist. About 50 others were injured.

\section{Conclusions}

To sum up, the very rational choice of terrorist methods needs to be stressed. Quite contrary to common opinion, a definite majority of such groups try to adapt their activities to the canons of their environment. Fearing loss of support, they do not usually choose forms which could provide true shock to the public opinion in their country or region. A specific conservatism of terrorists is also noticeable. The phenomenon itself is definitely undergoing a revolution, yet within the last century and a half, it has changed much less than other combat strategies. As a matter of fact, the perpetrators go back to the "same old" methods - bomb attacks, kidnappings, assassinations - and only diversify them in some way in order to draw public attention. The "modernisation" of terrorism consists thus mainly in seeking new scenarios, as well as in growing brutality and more and more frequent breaking of a taboo. The modernity (or post-modernity) of the newest wave of terrorism paradoxically finds expression in using more and more primitive means, like swords, axes, or poisons. That same tendency is also shown by more direct contact of terrorists with their victims than there was in the 1970s. Those tendencies are quite contrary to what can be observed in classical battlefields, where smart weapons allow increasing distance and keeping the victims anonymous.

The coming years will certainly bring new methods of executing terrorist attacks, although everyone hopes that the fight against terrorism will finally bring the desired outcomes.

\section{References}

[1] Robert Borkowski, Terroryzm (Terrorism), [in:] Robert Borkowski [ed.] Konflikty wspótczesnego świata (Conflicts of the Modern World), Kraków 2001, pp. 115-116;

[2] https://www.state.gov/j/crt/2015/257526.htm [06.03.2017];

[3] Ibidem;

[4] R. Olszewski, Reagowanie na zagrożenia z powietrza w czasie pokoju (Reacting to AirBorne Threats in the Time of Peace) [in:] Bezpieczne niebo (Safe Sky), proceedings from a scientific conference organised in the National Defence Academy on $10^{\text {th }}$ September 2002, AON, Warszawa 2002, p.51;

[5] M. Piekarski "Strategia i taktyka terrorystów" ("Terrorist Strategy and Tactics") http://www.antyterroryzm.republika.pl/Strategia i taktyka terroryst $\% \mathrm{C} 3 \% \mathrm{~B} 3 \mathrm{w} . \mathrm{pdf}$ [17.03.2017];

[6] https://www.state.gov/j/crt/2015/257526.htm [06.03.2017];

[7] M. Tomczak, Ewolucja metod terrorystycznych (Evolution of Terrorist Methods) http://studiastrategiczne.amu.edu.pl/wp-content/uploads/2010/10/17 tomczak.pdf [17.03.2017]. 